> Gi respons på artikler gjennom artiklenes kommentarfelt på tidsskriftet.no.

Innleggene publiseres fortløpende på Tidsskriftets nettside og et utvalg

av innleggene publiseres også i papirutgaven i spalten «Brev til redaktøren».

Redaksjonen forbeholder seg retten til å foreta redaksjonelle endringer.

Forfattere av vitenskapelige artikler har tilsvarsrett, jf. Vancouver-gruppens regler.

\section{Re: Flere og gale diagnoser med kriteriebasert diagnostikk}

I Tidsskriftet nr. 16/2015 henviser Pål Gjerden blant annet til kriteriebasert diagnostikk fra de tre siste nasjonale faglige retningslinjene for psykiatri fra Helsedirektoratet (1). Som delaktige i utarbeidelsen av retningslinjene og leder av den nasjonale kompetansetjeneste som forvalter retningslinjene, ønsker vi å komme med noen kommentarer til innlegget.

I motsetning til Gjerden mener vi at skjema for screening og diagnostikk har gitt en betydelig bedring for pasientene ved at diagnosene er blitt mer treffsikre og at flere pasienter dermed får rett behandling (2). Selv om skjemaer ikke er ideelle, betyr det ikke at de ikke kan være gode hjelpemidler. Det påligger alle å bruke skjemaene med forsiktighet, slik all informasjon vi henter inn må settes inn i en klinisk sammenheng. Dette gjelder i minst like stor grad ved somatisk sykdom, hvor nye diagnostiske hjelpemidler kan føre til overdiagnostikk og overbehandling om ikke det kliniske skjønn tas med i vurderingen.

Gjerden skriver at ikke én eneste retningslinje nevner muligheten for falskt positive diagnoser som uheldige konsekvenser av å stole på kriteriebaserte diagnoseskjemaer. Det er ikke riktig. For eksempel har psykoseretningslinjen en grundig gjennomgang av disse forhold (3): «Diagnostisering er også beheftet med ulemper, og innen psykisk helsevern må en derfor være særlig oppmerksom på mulige uheldige sider ved diagnoser. Den viktigste ulempen er faren for at en reduserer mennesket til diagnosen, slik at en glemmer å se det hele mennesket bak diagnosen. Diagnoser kan virke overforenklende med hensyn til å se hele den kompleksiteten som skjuler seg bak. Diagnoser kan også virke stigmatiserende og bidra til selvstigma», og «Diagnostisering ved psykoselidelser kan også være særlig utfordrende på grunn av potensielt kompliserte differensialdiagnostiske vurderinger og mange samtidige lidelser» (s. 124). Vi er enige $i$ at dette bør presiseres også i andre retningslinjer ved nye gjennomganger. Det er imidlertid vår erfaring at feildiagnostisering på grunn av synsing og manglende bruk av diagnostiske instrumenter fortsatt er et større problem enn overdiagnostisering.

Hele fundamentet for god og sikker diagnostikk knyttet til våre klassifikasjonssystemer bygger på bruk av diagnostiske instrumenter. Vi mener det blir helt feil å skrote et system uten å erstatte det med noe annet, selv om det ikke er perfekt. Retningslinjer, og de kommende «pakkeforløp», skal sikre at pasientene får korrekt behandling, og den nødvendige mengde. Det må ikke bety at «one size fits all». I dag er vi imidlertid nærmere den andre grøften, hvor pasienter og pårørende får et for dårlig og for lite omfattende behandlingstilbud, med tilhørende for dårlig behandlingsresultat. Pakkeforløp, brukt på en forstandig måte, vil sammen med retningslinjene gi pasienter større rettigheter til riktig behandling.

\section{Lars Lien}

lars.lien@sykehuset-innlandet.no

Jan Olav Johannessen

Lars Lien (f. 1960) er leder for Nasjonal kompetansetjeneste for samtidig rusmisbruk og psykisk lidelse.

Ingen oppgitte interesse konflikter.

Jan Olav Johannessen (f. 1951) er forskningsleder ved Psykiatrisk divisjonen, Stavanger universitetssykehus.

Ingen oppgitte interessekonflikter.
Litteratur

1. Gjerden P. Flere og gale diagnoser med kriteriebasert diagnostikk. Tidsskr Nor Legeforen 2015; 135: 1437

2. Nakash O, Nagar M, Kanat-Maymon Y. Clinical use of the DSM categorical diagnostic system during the mental health intake session. J Clin Psychiatry 2015: 76: e862-9.

3. Psykoselidelser (IS-1957). Oslo: Helsedirektoratet, 2013. https://helsedirektoratet.no/retningslinjer/nasjonal-faglig-retningslinje-forutredning-behandling-og-oppfolging-av-personer-med-psykoselidelser (16.9.2015).

\section{P. Gjerden svarer:}

Lars Lien \& Jan Olav Johannessen forsvarer psykoseretningslinjen (1). De mener at denne retningslinjen omtaler muligheten for falskt positive diagnoser som konsekvens av å stole på kriteriebaserte diagnoseskjema. Det gjør den ikke. Det den imidlertid gjør er å peke på mulige uheldige sider ved diagnoser helt generelt, at diagnoser kan være reduserende, overforenklende og stigmatiserende. Dette er selvfølgelig sant. Men retningslinjen nevner ikke med et eneste ord risikoen for at diagnosen kan være uriktig, at det settes en feilaktig psykosediagnose på en ikke-psykotisk pasient.

$\AA$ vente litt med å stille en psykosediagnose er ingen uopprettelig feil. Å stille en feilaktig psykosediagnose kan være en tragedie. Dette er ikke problematisert på noen av psykoseretningslinjens 217 sider.

Lien \& Johannessen påstår videre at «Hele fundamentet for god og sikker diagnostikk knyttet til våre klassifikasjonssystemer bygger på bruk av diagnostiske instrumenter». Hva de mener med «god og sikker» er uklart for meg. Hvis de mener valid og reliabel, har jeg allerede kommentert det i mitt innlegg. Det kan være flere grunner til å opprettholde et klassifikasjonssystem, men å tro at det representerer virkeligheten mener jeg er en vrangforestilling.

Når de til slutt kommenterer kommende «pakkeforløp» som skal sikre at pasientene får «korrekt og nødvendig mengde behandling», får jeg frysninger på ryggen. Jeg har ikke drøftet denne problemstillingen i mitt opprinnelige innlegg og det er ikke plass til å kommentere det utfyllende her. Jeg anbefaler i stedet å lese kollegene Henrik Vogt \& Andreas Saxlund Pahles kronikk i Morgenbladet 11. september i år, «Likeverd på samlebånd» (2).

Jeg er glad for at Lien \& Johannessen mener at skjemaer må brukes med forsiktighet og settes inn i en klinisk sammenheng. Min erfaring er at disse skjemaene i stadig større grad får status som sannhet. En skal være nokså faglig trygg på seg selv for å avvise en skjemabasert diagnose, eller holde på en diagnose selv om skjemaet ikke bekrefter den.

\section{Pål Gjerden}

pal.gjerden@sthf.no

Pål Gjerden (f. 1956) er spesialist i psykiatri og overlege ved Psykiatrisk klinikk, Sykehuset Telemark.

Ingen oppgitte interessekonflikter.

Litteratur

1. Psykoselidelser (IS-1957). Oslo: Helsedirektoratet, 2013 https://helsedirektoratet.no/retningslinjer/nasjonal-faglig-retningslinje-forutredning-behandling-og-oppfolging-av-personer-med-psykoselidelser (25.9.2015).

2. Vogt $H$, Pahle AS. Likeverd på samlebånd. Morgenbladet 11.09.2015. http://morgenbladet.no/ideer/2015/09/likeverd-pa-samleband (25.9.2015) 